\title{
Response of Haricot Bean (Phaseolus Vulgaris L.) Varieties to Drought Stress at Different Growth Stages
}

\author{
Awoke Wasae $^{1} \quad$ Berehanu Abate $^{2}$ Walelign Worku ${ }^{2}$ \\ 1.Plant Science Department, Debark University, Ethiopia \\ 2. School of Plant and Horticultural Sciences, Hawassa University, Ethiopia
}

\begin{abstract}
Drought is considered as the single most devastating environmental factor, which decreases crop yield more than the collective effect of other environmental factors. Varieties also differ in their reaction to drought stress, when they exposed to drought stress at different growth stages. Pot experiment was conducted at Hawassa College of Agriculture, southern Ethiopia, with objectives of identifying relatively drought tolerant haricot bean varieties and yield correlated traits under drought stress at different growth stages. Ten improved haricot bean varieties were subjected to drought stress by withholding water for 15 days at vegetative, flowering and pod-setting stages. The analysis of variance showed that phenology, growth and yield components were affected by both drought stress and varieties. However, their interaction effect was significant only for number of seeds plant ${ }^{-1}$, seed yield and pod harvest index. Drought intensity indices at vegetative, flowering and pod setting stages were 0.046, 0.335 and 0.249 respectively. Drought at vegetative, flowering and pod setting stages reduces seed yield by 2.91 , 33.53 and $25.11 \%$ respectively as compared to full irrigation. Plant height, branches, pods and seeds plant ${ }^{-1}$ and 100 seed weight were reduced most by the stress induced at flowering followed by pod setting stages. However, there was no statistical difference between the effects of drought stress at vegetative stage and full irrigation on all measured parameters. Varieties with higher yields under flowering stress were H/dumme (21.96g plant $\left.{ }^{-1}\right)$, Wajo(21.38g plant $\left.{ }^{-1}\right)$ and Nasir(17.45g plant $\left.{ }^{-1}\right)$ on the other hand Wajo (30.57g plant $\left.{ }^{-1}\right), \mathrm{H} / \mathrm{dumme}\left(22.6 \mathrm{~g}\right.$ plant $\left.{ }^{-1}\right)$ and Ibbado(30.45g plant $\left.{ }^{-1}\right)$ had better yield performance under full irrigtaion. Seed yield had significant and positive correlation with pod harvest index, days to maturity, number of pods on the main stem, seed plant ${ }^{-1}, 100$ seed weight and plant height, which can be used as a selection index to screen drought tolerant haricot bean varieties. To achieve high yield, drought must be avoided during flowering and pod-setting stages, and varieties $\mathrm{H} /$ dumme, Wajo and Nasir can be recommended for drought prone areas.
\end{abstract}

Keywords: Drought stress, drought tolerance, Phaseolus vulgaris L.

DOI: $10.7176 / \mathrm{JBAH} / 9-1-05$

\section{INTRODUCTION}

Haricot bean (Phaseolus vulgaris L.) is an important legume crop grown worldwide. It was most likely introduced to Ethiopia by the Portuguese in the $16^{\text {th }}$ century (Fisseha, 2015). Haricot bean is grown in central, southern, eastern, western lowlands and mid altitudes (1400-2000 m.a.s.l) of Ethiopia as a food and cash crop and produced predominantly by smallholder producers (Karanja et al., 2011; CSA, 2016). It is a food-secure crop as it contains protein, carbohydrate, fat and minerals substituting the animal products which are not affordable to buy by the majority of poor farmers (Schwartz et al., 1996). Haricot bean is cultivated as a sole crop in rotation with cereals (Wortmann, 2006) and intercropped under row planted crops like maize and sorghum.

The national average yield of haricot bean in Ethiopia is 1.69t/ha (CSA, 2016), which is low as compared to the yield (2.5-3.6 t/ha) achieved at research centers (MoANR, 2016). There are many natural and agronomic factors hindering exploitation of the yield potential of this crop. Drought stress at different growth stages and growing of local and old varieties were the major production constraints. Drought is considered as the single most devastating environmental stress, which decreases crop productivity more than the combined effect of other environmental factors (Lambers et al., 2008; Shao et al., 2009). Even if there is an adequate average annual rainfall in Ethiopia, the production of sustainable and reliable food supply is becoming very difficult due to temporal and spatial imbalance in the distribution of rainfall and recurrent shortage of water at the required period. Most of haricot bean growing regions in Ethiopia have erratic rainfall distribution and sandy soil with low moisture holding capacity (Simane and Slruik, 1993). Drought is the most important factor limiting the productivity of rain fed production of different pulse crops in southern Ethiopia where this study was conducted (Saxena et al., 1993).

Often crop failure occurs because of unavailability of water at some critical growth stages (Benjamin et al., 2003; Demirevska et al., 2009). However, there were controversial evidences on the effect of drought stress at different growth stages. Some scholars reported that drought stress at vegetative stage is good (Sangakkara, 1994; Nautiyal et al., 2002; Jaleel et al., 2008). However, other scholars argue that drought stress at vegetative stage is sever than that of flowering and pod setting stress (Bolanos and Edmeas, 1993; Mustapha, 2014). Most of the researchers reported and agreed that flowering and pod setting stresses are the most sensitive, while vegetative 
stress is the least (Vijitha and Mahendran, 2010, Walelign and Skjelvag, 2006).

Varieties also differ in their response to drought stress and other environmental constraints, when they exposed at different growth stages (Wortman et al., 1995; Manjeru et al., 2005; Porch et al., 2013). Effect of drought on crop performance is usually minimized by growing drought tolerant and early maturing varieties, moisture conservation, and/or supplemental irrigation. According to MoANR (2016) Ethiopian Lowland pulse breeding program released about 57 improved varieties with yield range of 2.0-3.6 t/ha at research fields, but they are not yet evaluated for their drought tolerance at different growth stages. Therefore, the finding of this study will help farmers to adjust time of sowing by synchronize the sensitive growth stage to the time of adequate rainfall. Furthermore, to use their irrigation water efficiently and economically by irrigating the crop according to the sensitivity of growth stages. The objectives of the study were to identify relatively drought tolerant haricot bean varieties and yield correlated traits under drought stress at different growth stages.

\section{MATERIALS AND METHODS}

\section{Haricot bean varieties and moisture regimes}

The study was conducted on ten improved varieties of haricot bean (SER-119, Tatu, SAB-632, SER-115, Kat-B9, H/dumme, Ibbado, Wajo, Nasir and Red-Wolaita) released in different years by South Agricultural Research Institute (SARI) and Melkassa Agricultural Research Center (MARC) in Ethiopia. Four moisture regimes namely, full irrigation, drought stress at vegetative, flowering and pod setting stages for 15 days duration were applied. As explained by CIAT (1986) the drought stress was initiated at three developmental stages; (i) at the first compound leaf stage i.e. when the first trifoliate leaf appears open and flat on $50 \%$ of the plants [V3]; (ii) at flowering stage i.e. when the first open flower appears by $50 \%$ of the plants [R6]; and (iii) at pod setting stage i.e. when $50 \%$ of the plants show the first pod with the flowers corolla hanging or detached from a crop [R7].

\section{Experimental design and procedures}

The experiment was carried out in green house using a $4 \times 10$ factorial experiment laid out in a split plot arrangements with water regimes constituting the main plots and varieties as sub plots. Wooden bench was constructed inside of the green house so that all pots laid on over it. Thermometer was also installed to measure daily internal temperature. Plastic pots with 20 liter capacity perforated at the bottom were filled with top soil collected up to $30 \mathrm{~cm}$ depth from Hawassa College of Agriculture Research field. Six seeds of each haricot bean variety were planted in each pot and two weeks after sowing the seedlings were thinned to three per pot. All pots were well watered with three days interval until commencement of drought stress treatments. One day before starting the treatments, soil moisture in each pot was maintained to field capacity for the purpose of keeping uniform soil moisture at each pot. At the first compound leaf stage, irrigation was completely cut off for vegetative stress treatment for 15 days and then normal irrigation was applied. The same procedure was employed when the plant reached at flowering and pod setting stages. Amount of water to be applied was determined by measuring the soil moisture content using Delta-T-Device, Model HH2, which was installed at $12 \mathrm{~cm}$ depth inside of pots, and watering was done based on root zone depletion as explained by FAO (2012).

$\operatorname{Dr}=\operatorname{Wr}(\mathbf{f c})-\operatorname{Wr}(\mathbf{t})=\mathbf{1 0 0 0}(\boldsymbol{\theta f} \mathbf{c}-\boldsymbol{\theta t}) \mathrm{Z}$

Where $\operatorname{Dr}=$ root zone depletion $(\mathrm{mm}), \mathrm{Wr}(\mathrm{fc})=$ soil water content of the root zone at field capacity $(\mathrm{mm}), \mathrm{Wr}(\mathrm{t})=$ soil water content of the root zone expressed as depth $(\mathrm{mm}), \boldsymbol{\theta} \mathrm{fc}=$ volumetric water content at field capacity $\left(\mathrm{m}^{3} / \mathrm{m}^{3}\right), \boldsymbol{\theta} \mathrm{t}=$ volumetric water content in the root zone $\left(\mathrm{m}^{3} / \mathrm{m}^{3}\right), \mathrm{Z}=$ effective rooting $\operatorname{depth}(\mathrm{m})$

\section{Data Collection and Analysis}

Days to $50 \%$ flowering and $75 \%$ maturity were counted from date of emergence. Number of branches per plant, number of pods on different stem axis and seed per plant were counted. Hundred seed weight (g) was determined by taking weight of 50 randomly picked seeds from the total harvest and multiplied by two. Seed yield $\left(\mathrm{g}\right.$ plant $\left.{ }^{-1}\right)$ was recorded on plant basis and adjusted to $10 \%$ standard grain moisture content of pulse. Pod harvest index was calculated as the ratio of adjusted dry weight of seed at harvest to dry weight of pods at harvest. Drought susceptibility index (DSI), drought tolerance index (DTI), percentage of yield reduction due to drought (PYR), geometric mean (GM), mean productivity (MP) and yield stability index (YSI) were calculated to screen tolerant varieties and to identify sensitive growth stages. Each index' methods were calculated for the three drought stress levels (vegetative, flowering \& pod setting) against the yield obtained from the full irrigation treatment. Drought tolerance indices methods were calculated based on the following formula.

$$
\begin{aligned}
& \text { DII }=1-\left(\frac{Y s}{Y p}\right) \text { (Fischer and Maurer, 1978), DTI }=\frac{\left(\text { Ysi } *\left(\frac{Y s i}{Y p i}\right)\right)}{Y s}(\text { Blum, 1988), } \\
& \text { DSI }=\frac{\left|1-\left(\frac{\mathrm{Ysi}}{\mathrm{Ypi}}\right)\right|}{\left|1-\left(\frac{\mathrm{Ys}}{\mathrm{Yp}}\right)\right|}(\text { Fischer\&Maurer }, 1978), \mathrm{MP}=\frac{(\mathrm{Ypi}+\mathrm{Ysi})}{2}(\text { Rosielle and Hamblin, 1981), } \\
& \text { PYR }(\%)=\frac{(\text { Ypi-Ysi })}{\text { Ypi }} * 100(\text { Farshadfar \& Javadinia }, 2011) \text {, }
\end{aligned}
$$


$\mathrm{GM}=(\sqrt{\mathrm{Ypi}} *$ Ysi $)\left(\right.$ Fernandez, 1992), YSI $=\left(\frac{\mathrm{Ysi}}{\mathrm{Ypi}}\right)$ Bouslama and Schapaugh (1984)

Where $\mathrm{Ysi}=$ average yield of variety $\mathrm{i}$ in stressed condition, $\mathrm{Ypi}=$ average yield of the same variety under non-stress condition, $\mathrm{Ys}=$ average yield of all varieties under stress condition, $\mathrm{Yp}=$ average yield of all varieties under non-stress condition

The analysis of variances and correlation coefficients were analyzed using SAS software version 9.2, 2008. Treatment means were compared using the Least Significant Difference (LSD) test at $5 \%$ level of significance.

\section{RESULTS AND DISCUSSION}

Physico-chemical properties of the soil used for the experiment

The laboratory soil analysis results showed that the soil has loam texture and slightly alkaline $\mathrm{pH}$ of 7.44 which is in preferred range for haricot bean production. Bulk density (BD) and cation exchange capacity (CEC) of the soil indicated that the soil is good agricultural soil (Table 1).

Table 1. Some physical and chemical properties of the soil used for the experiment

\begin{tabular}{|c|c|c|c|c|c|c|c|c|}
\hline \multicolumn{3}{|c|}{ Particle size (\%) } & $\mathrm{pH}$ & FC & PWP & $\mathrm{BD}$ & OM & CEC \\
\hline Sand & Silt & Clay & $1: 2: 5 \mathrm{H}_{2} \mathrm{O}$ & $\%$ & $\%$ & $\mathrm{~g} / \mathrm{cm}^{3}$ & $\%$ & $\mathrm{meq} / 100 \mathrm{gm}$ \\
\hline 48.23 & 33.13 & 18.64 & 7.44 & 21.41 & 10.53 & 1.19 & & \\
\hline
\end{tabular}

Temperature during crop growth period in the green house

The daily minimum, maximum and average temperature during crop growth period was $\left(17-26^{\circ} \mathrm{c}\right),\left(28-41^{\circ} \mathrm{c}\right)$ and $\left(24-32^{\circ} \mathrm{c}\right)$ respectively. The daily Average temperature was beyond the optimum for the growth of haricot bean varieties. As a result considerable flower and pod abortion as well as pollen infertility is expected (Amare, 1989; Suzuki et al., 2003). This high temperature is because of plastic coverage of green house.

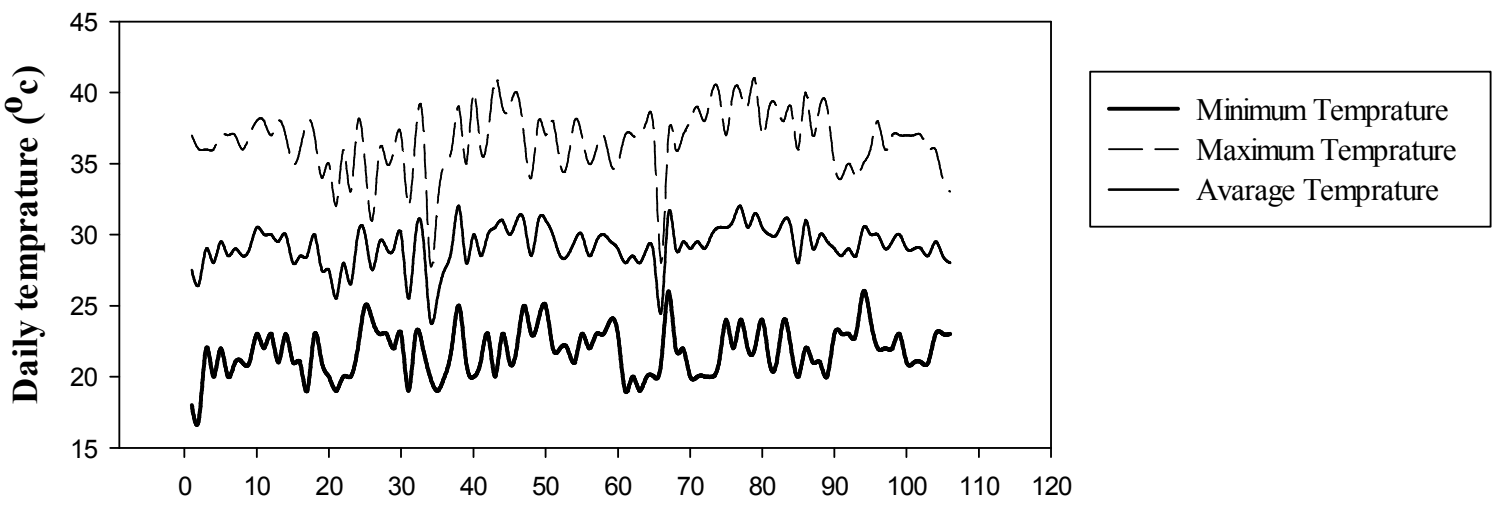

Days from sowing

Figure 1. Daily minimum, maximum and average temperatures during crop growth period

Effects of moisture regimes and varieties on phenology of Haricot Bean

Results of the analysis of variance revealed that the effects of varieties was significant $(\mathrm{P}<0.001)$ on days to emergence, flowering and maturity, while days to flowering and maturity were also affected by moisture regimes $(\mathrm{P}<0.001)$. However, the interaction effect of varieties and moisture regimes was not significant. Varieties Wajo, Tatu and SER-119 were emerged early, while Ibbado, SAB-632 and Kat-B9 were late (Table2) due to their inherent genetic variation. Drought stress imposed at vegetative stage extended days to flowering by an average of 2.9 and days to maturity by 4.1 days as compared to full irrigation. Conversely, drought stress during pod setting stage results in earlier maturity (Table 2). Variety Kat-B9 had the earliest days to flowering and maturity followed by variety SAB-632 while, varieties Wajo and Ibbado were late across moisture regimes.

The difference in days to flowering and maturity among varieties might be attributed to genotypic variation as reported by Kwabena et al. (2016) and Rezene et al. (2013). The possible reason for the delaying of days to maturity is that it starts to recover by initiating new leaves when the treatments were re-watered at the end of stress period. The result was in line with Beshir et al., (2015) who reported that drought stress at vegetative stage delayed maturity.

Effects of moisture regimes and varieties on plant height and branches per plant

Plant height and number of branches per plant were significantly $(\mathrm{p}<0.001)$ influenced by the main effects of moisture regimes and varieties, but the interaction effect was not significant. The highest plant height was recorded from the full irrigation treatment, which was statistically comparable with stress at vegetative stage, while flowering and pod setting stages had the lowest plant height (Table 2). Variety Nasir had the highest plant height followed by Ibbado, while the lowest plant height was recorded for SAB-632 and Tatu. The highest 
number of branches per plant was recorded for SAB-632 and followed by Nasir, while the lowest was recorded for Ibbado and Tatu. The difference in plant height among varieties is attributed to inherent genotypic variability. The highest plant height in full irrigation treatment may be due to the fact that moisture availability stimulates stem elongation through enhancement of cell division and expansion (Hussain et al., 2008). The result is in agreement with the findings of (Walelgn and Skjelvag, 2006; Emam., 2010; Kwabena et al., 2016) who reported that reduction in plant height was observed under stress condition. Under drought stress at vegetative stage reduction in number of branch per plant was observed, since under stress condition plants only supports the growth of main stem and minimize number of branches per plant. Varieties with highest plant height and number of branches are preferred for drought stressed areas since it increases the chance of flower initiation on different plant axis.

\section{Effects of moisture regimes and varieties on yield components of haricot bean \\ Number of pods on different stem axis}

Number of pods on main stem, branches and pods per plant were significantly $(\mathrm{P}<0.001)$ affected by moisture regimes and varieties, but their interaction effect was not significant. As compared to full irrigation treatment, drought stress imposed at flowering stage significantly reduced number of pods on main stem, branches and pods per plant by $25.81,53.52$ and $36.07 \%$ respectively. The result further indicated that number of pods on the branch $(53.52 \%)$ was affected more than pods on the main stem (25.81\%) (Table 2). Barrios et al. (2005) also reported that soil water deficits may affect the location and pattern of flower and pod production on different stem axes of a bean plant. On this aspect, under drought stress, varieties which initiate most of their pods on the main stem like H/dumme, SER-119 and Kat-B9 are prefered. The possible explanation for this might be, under drought stress there was high reduction in growth parameters of branches as compared to the main stem (Barrios et al., 2005).

The highest number of pods on main stem was obtained from varieties H/dumme, Nasir and Kat-B9, while the lowest number of pods on main stem was recorded for Ibbado and Red-Wolaita (Table 2). The highest number of pods on branches was obtained from variety SER-119 and the lowest was recorded for varieties H/dumme, Nasir and Wajo. Over all SER-119 had the highest number of pods per plant followed by H/dumme, while Tatu and SAB-632 had the lowest number of pods per plant (Table 2). Genotypic difference in yield components of haricot bean varieties both under drought stress and non-stress conditions was also reported by Rezene et al., (2013) and Kwabena et al, (2016).

\section{Hundred Seed weight}

The effect of moisture regimes and varieties on hundred seed weight was significant $(\mathrm{P}<0.001)$ but their interaction effect was not significant. The highest hundred seed weight was recorded for full irrigation treatment and drought stress at vegetative stage, while drought stress at pod setting stage had got the lowest hundred seed weight (Table 2). Low 100 seed weight from genotypes exposed to drought stress was also reported by Manjeru et al., (2005), Rezene et al., (2013) and Kwabena et al.,(2016).Varieties Ibbado, SAB-632 and Kat-B9 had highest hundred seed weight, while varieties Nasir, H/dumme, SER-119 had lowest hundred seed weight

\section{Number of seeds per pod}

Number of seeds per pod was significantly $(\mathrm{P}<0.001)$ different among varieties. The highest number was recorded for Nasir, Wajo and H/dumme, while the lowest was for Tatu, SAB-632 and Ibbado (Table 2). The difference in the number of seeds per pod mainly attributed to abortion of ovules and difference in seed size among varieties. Varieties that have larger seed size like SAB-632 and Tatu had less number of seeds per pod. Drought stress interferes with pollination and causes embryo abortion (Gardner et al., 1985). 
Table 2.Mean Phenology, growth, yield and yield components of haricot bean varieties under different moisture regimes imposed at different growth stages

\begin{tabular}{|c|c|c|c|c|c|c|c|c|c|c|}
\hline \multirow[b]{2}{*}{ Treatments } & \multicolumn{10}{|c|}{ Mean } \\
\hline & DE & DF & DM & PH & NBPP & NPMS & NPB & NPPP & NSPP & 100SW \\
\hline \multicolumn{11}{|l|}{$\begin{array}{l}\text { Moisture } \\
\text { regimes }\end{array}$} \\
\hline Full-irrigation & 7.30 & $30.03^{b}$ & $71.20^{\mathrm{c}}$ & $44.85^{\mathrm{a}}$ & $3.98^{\mathrm{a}}$ & $8.29^{\mathrm{a}}$ & $4.97^{\mathrm{a}}$ & $13.25^{\mathrm{a}}$ & 5.75 & $30.89^{\mathrm{a}}$ \\
\hline Vegetative & 7.37 & $32.97^{\mathrm{a}}$ & $75.30^{\mathrm{a}}$ & $44.64^{\mathrm{a}}$ & $3.42^{c}$ & $8.11^{\mathrm{a}}$ & $4.96^{\mathrm{a}}$ & $13.07^{\mathrm{a}}$ & 5.56 & $30.82^{\mathrm{a}}$ \\
\hline Flowering & 7.30 & $30.13^{b}$ & $72.50^{\mathrm{b}}$ & $41.23^{b}$ & $3.71^{\mathrm{b}}$ & $6.15^{\mathrm{c}}$ & $2.31^{\mathrm{c}}$ & $8.47^{\mathrm{c}}$ & 5.47 & $28.87^{\mathrm{b}}$ \\
\hline Pod-setting & 7.13 & $30.17^{\mathrm{b}}$ & $66.23^{d}$ & $39.43^{b}$ & $3.80^{\mathrm{b}}$ & $7.15^{b}$ & $4.01^{\mathrm{b}}$ & $11.17^{\mathrm{b}}$ & 5.14 & $27.52^{\mathrm{c}}$ \\
\hline LSD (5\%) & Ns & 0.66 & 0.46 & 1.90 & 0.13 & 0.36 & 0.31 & 0.66 & Ns & 0.98 \\
\hline \multicolumn{11}{|l|}{ Varieties } \\
\hline SER-119 & $7.08^{b}$ & $31.08^{\mathrm{cb}}$ & $72.17^{\mathrm{d}}$ & $46.28^{c}$ & $3.56^{\mathrm{fe}}$ & $8.33^{\mathrm{bc}}$ & $7.14^{\mathrm{a}}$ & $15.47^{\mathrm{a}}$ & $5.52^{c}$ & $21.62^{f}$ \\
\hline Tatu & $7.08^{\mathrm{b}}$ & $29.33^{\mathrm{d}}$ & $70.00^{\mathrm{e}}$ & $34.50^{\mathrm{e}}$ & $3.39^{\mathrm{hg}}$ & $4.92^{\mathrm{f}}$ & $2.14^{\mathrm{f}}$ & $7.05^{\mathrm{f}}$ & $4.21^{\mathrm{d}}$ & $31.24^{\mathrm{d}}$ \\
\hline SAB-632 & $7.92^{\mathrm{a}}$ & $29.42^{\mathrm{d}}$ & $66.67^{\mathrm{g}}$ & $33.36^{\mathrm{e}}$ & $4.34^{\mathrm{a}}$ & $4.72^{\mathrm{f}}$ & $1.78^{\mathrm{f}}$ & $6.5^{\mathrm{f}}$ & $4.51^{\mathrm{d}}$ & $40.54^{\mathrm{ba}}$ \\
\hline SER-125 & $6.83^{\mathrm{b}}$ & $31.25^{\mathrm{cb}}$ & $67.92^{\mathrm{f}}$ & $43.25^{\mathrm{d}}$ & $3.89^{c}$ & $7.47^{\mathrm{d}}$ & $5.14^{\mathrm{b}}$ & $12.61^{\mathrm{cb}}$ & $5.97^{\text {bac }}$ & $24.64^{\mathrm{e}}$ \\
\hline Kat-B9 & $7.75^{\mathrm{a}}$ & $27.83^{\mathrm{e}}$ & $66.75^{\mathrm{g}}$ & $27.25^{\mathrm{f}}$ & $3.53^{\mathrm{fg}}$ & $8.89^{\text {ba }}$ & $2.64^{\mathrm{e}}$ & $11.53^{\mathrm{d}}$ & $5.46^{\mathrm{c}}$ & $39.51^{\mathrm{b}}$ \\
\hline $\mathrm{H} /$ dumme & $7.00^{\mathrm{b}}$ & $30.83^{c}$ & $70.33^{\mathrm{e}}$ & $42.42^{\mathrm{d}}$ & $3.69^{\mathrm{de}}$ & $9.14^{\mathrm{a}}$ & $4.25^{\mathrm{c}}$ & $13.38^{\mathrm{b}}$ & $5.67^{\mathrm{bc}}$ & $21.12^{\mathrm{f}}$ \\
\hline Ibbado & $8.00^{\mathrm{a}}$ & $31.67^{\mathrm{b}}$ & $74.75^{\mathrm{c}}$ & $51.44^{\mathrm{b}}$ & $3.25^{\mathrm{h}}$ & $6.69^{\mathrm{e}}$ & $3.28^{\mathrm{d}}$ & $9.97^{\mathrm{e}}$ & $5.52^{\mathrm{c}}$ & $41.02^{\mathrm{a}}$ \\
\hline Wajo & $7.12^{b}$ & $33.92^{\mathrm{a}}$ & $79.08^{\mathrm{a}}$ & $47.25^{\mathrm{c}}$ & $3.74^{\mathrm{dc}}$ & $7.78^{\mathrm{dc}}$ & $4.47^{\mathrm{c}}$ & $12.25^{\mathrm{cd}}$ & $6.10^{\mathrm{ba}}$ & $32.81^{\mathrm{c}}$ \\
\hline Nasir & $7.00^{\mathrm{b}}$ & $31.67^{\mathrm{b}}$ & $72.00^{\mathrm{d}}$ & $54.11^{\mathrm{a}}$ & $4.05^{\mathrm{b}}$ & $9.03^{\mathrm{a}}$ & $4.42^{c}$ & $13.44^{\mathrm{b}}$ & $6.33^{\mathrm{a}}$ & $19.55^{\mathrm{g}}$ \\
\hline Red-Wolaita & $6.92^{\mathrm{b}}$ & $31.25^{\mathrm{cb}}$ & $75.92^{\mathrm{b}}$ & $45.55^{\mathrm{c}}$ & $3.83 \mathrm{~d}^{\mathrm{c}}$ & $7.31^{\mathrm{de}}$ & $5.39^{\mathrm{b}}$ & $12.69^{\mathrm{cb}}$ & $5.52^{\mathrm{c}}$ & $23.17^{\mathrm{e}}$ \\
\hline CV (\%) & 7.36 & 2.92 & 1.24 & 5.75 & 5.27 & 10.67 & 14.59 & 9.68 & 12.98 & 6.28 \\
\hline LSD (5\%) & 0.44 & 0.73 & 0.72 & 1.99 & 0.16 & 0.64 & 0.48 & 0.91 & 0.58 & 1.51 \\
\hline
\end{tabular}

Where $\mathrm{DE}=$ days to emergence, $\mathrm{DF}=$ days to flowering, $\mathrm{DM}=$ days to maturity, $\mathrm{PH}=$ plant height, $\mathrm{NBPP}=$ number of branch per plant, NPMS=number of pods on main stem, NPB=number of pods on branch, NPPP=number of pods per plant, $\mathrm{NSPP}=$ number of seeds per pod, $100 \mathrm{SW}=$ hundred seed weight, $\mathrm{CV}=$ coefficient of variation, LSD=least significance difference.

Number of seeds per plant, seed yield (g plant $\left.{ }^{-1}\right)$ and pod harvest index

Number of seeds per plant, seed yield and pod harvest index were significantly $(\mathrm{P}<0.001)$ affected by the interaction effect of moisture regimes and haricot bean varieties. Across all moisture regimes, variety Nasir produced the highest number of seeds per plant under both full irrigation and drought stress at vegetative stage. The lowest number of seeds per plant was recorded for SAB-632 both under drought stress at flowering and pod setting stages (Figure 2). Manjeru et al. (2005) reported that the least reduction in yield and yield components of haricot bean was occurred when drought stress was imposed during the vegetative phase as compared to flowering and pod setting stages. In general varieties Nasir and Wajo were consistent in number of seeds per plant in both stress and non-stress conditions due to their indeterminate growth habit, which enable plants to produce new flowers and pods when there is enough moisture after drought.

Across all moisture regimes, the highest seed yield per plant was harvested from varieties Wajo and Ibbado under full irrigation. While, the lowest seed yield per plant was obtained from varieties SER-119, SAB-632 and Kat-B9 exposed for drought stress at flowering stage (Figure 2). Reduction in seed yield under stressed condition was mainly due to reduction in other yield components. In consideration of all moisture levels the highest pod harvest index (PHI) was obtained from Kat-B9 under non-stress condition. However, the lowest pod harvest index was obtained from Red-Wolaita under drought stress at flowering stage (Figure 2). Under drought stress conditions PHI was reduced in sensitive varieties and increased in resistant varieties, which indicates the importance of remobilization of photosynthates from pod wall to seed (Assefaet al. 2013). 

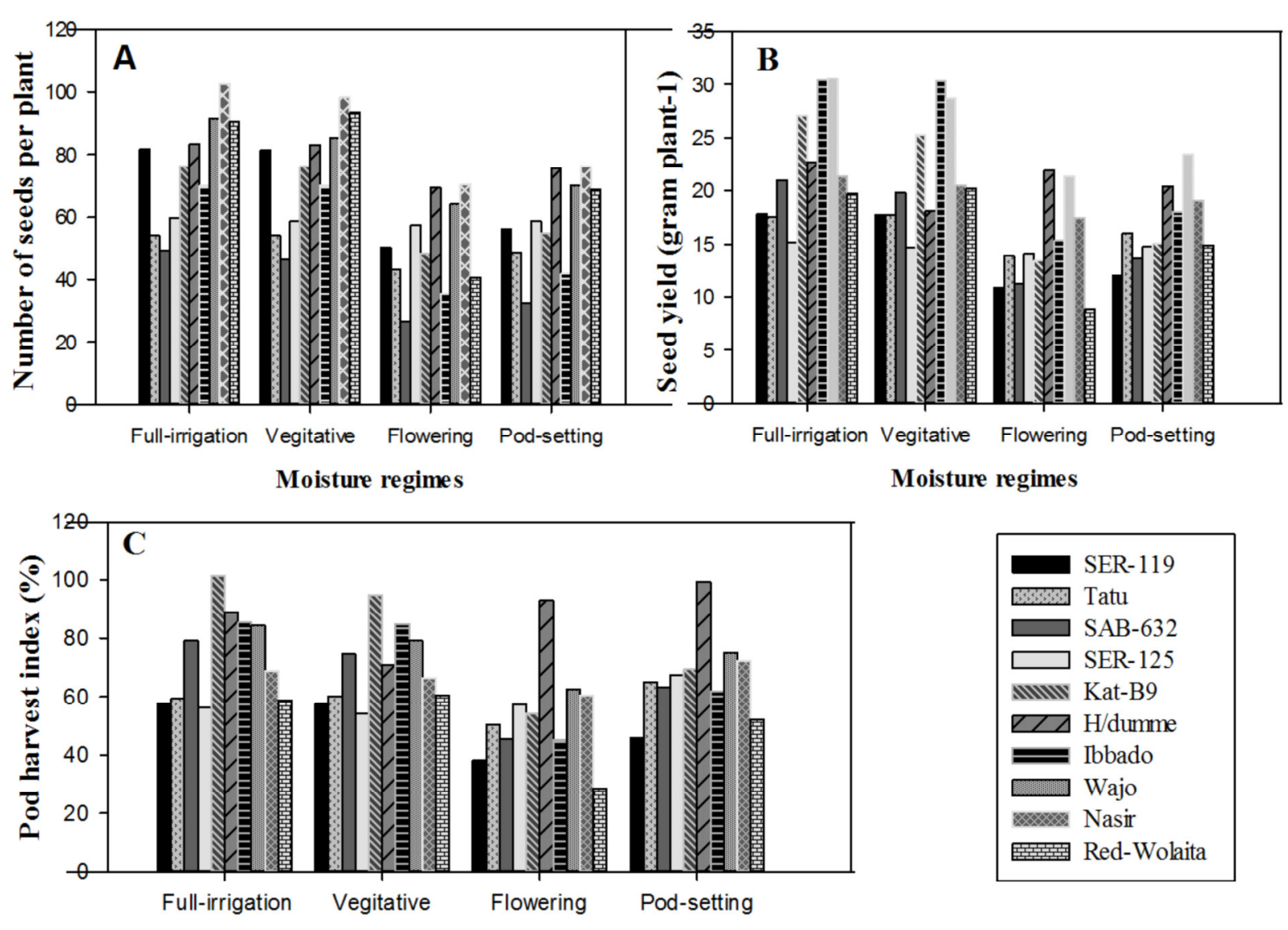

Moisture regimes

Figure 2. A. Interaction effect of moisture regimes and haricot bean varieties on number of seeds per plant, $\mathbf{B}$. Interaction effect of moisture regimes and haricot bean varieties on seed yield ( $\mathrm{g}$ plant $\left.{ }^{-1}\right)$, $\mathbf{C}$. Interaction effect of moisture regimes and haricot bean varieties on pod harvest index.

\section{Drought tolerance indices and their correlation to seed yield}

To quantify the severity of drought stress at different growth stages on grain yield, drought intensity index (DII) was calculated for this experiment. Accordingly DII was found to be, 0.046 (for drought stress at vegetative stage) which indicates minimal or no stress, 0.335 (for drought stress at flowering stage) which indicates moderate drought stress and 0.249 (for drought stress at pod setting stage) which indicates again moderate drought stress. The reason for less value of DII for drought stress at vegetative stage is that up on re-watering the crop had time to make further adjustment in its vegetative growth as well as yield and yield components (Walelign and Skjelvag, 2006). However, drought stress imposition during reproductive stage caused relatively higher value of DII, since drought stress at this stage causes abortion of flowers and ovules, senescence of flowers and pods, which all have direct relation with yield. Moderate drought stress have also been reported in haricot bean (Asfaw and Blair, 2014; Kwabena et al., 2016). Basically under moderate stress, varieties with high yield potential can be suitable whereas under severe stress varieties with high drought tolerance and low yield potential would be more beneficial (Panthuwan et al., 2002).

Drought stress imposition at flowering stage resulted in high values of DII, DSI, PYR and low values of DTI, GM, MP and YSI reflecting that flowering is the most sensitive growth stage to drought stress. However, drought stress imposition at vegetative stage resulted in high values of DTI, GM, MP, YSI and low values of DII, DSI and PYR reflecting it is the less sensitive stage to drought stress. The response of varieties also differed depending on the stage of drought stress commencement. H/dumme had high DSI values during stress at vegetative stage but low during flowering and pod setting stages and the reverse is true for Red-Wolaita. Regarding to all indices H/dumme, Wajo and Nasir were selected as drought tolerant because of their high DTI, GM, MP, YSI and low DSI and PYR values across all drought stress treatments (Table 3). Similar ranks of varieties were observed by GM and MP, which suggests that these two parameters have equal importance for selecting genotypes under stress and non-stress conditions (Mevlut and Sait, 2011).

Strong association between Ypi and Ysi $(0.96 * * *)$ depicting that high yield potential under full irrigation condition does anticipate superior yield under drought stress at vegetative stage. Therefore, indirect selection for stresses environment based on the performance of fully irrigated conditions would be effective. The result was in 
agreement with Panthuwan et al. (2002) and Rizza et al. (2004) who reported that under moderate stress, varieties with high yield potential are suitable. Under stress at vegetative stage Ysi is significantly and positively correlated with DTI $(0.97 * * *), \mathrm{GM}(0.99 * * *)$ and MP $(0.99 * * *)$. Under stress at flowering stage, the association between Ypi and Ysi was weak $\left(0.46^{\mathrm{NS}}\right)$ and non-significant. This result indicated that, since the stress is more severe than that of vegetative stage, indirect selection for stresses environment based on the performance of fully irrigated conditions would not be effective. The result was in agreement with Gholipouri et al. (2009) and Javed et al. (2011) who found weak association between Ypi and Ysi as the stress get stronger. Under stress at flowering stage Ysi had significant and positive correlation with DTI $(0.90 * *)$, GM $\left(0.88^{* *}\right)$ and MP $(0.82 * *)$, while significant and negative correlation with PYR $(-0.60 *)$ and DSI $\left(-0.60^{*}\right)$.

Table 3. Seed yield (g plant $\left.{ }^{-1}\right)$ under non-stress and drought stress, and drought tolerance indices of haricot bean varieties exposed to drought stress at different growth stages.

\begin{tabular}{|c|c|c|c|c|c|c|c|c|c|}
\hline $\begin{array}{l}\text { Moisture } \\
\text { regimes }\end{array}$ & Varieties & Ypi & Ysi & DSI & DTI & PYR & GM & MP & YSI \\
\hline \multirow[t]{2}{*}{ है } & SER-119 & 17.79 & 17.74 & 0.06 & 0.83 & 0.27 & 17.77 & 17.77 & 1.00 \\
\hline & Tatu & 17.55 & 17.72 & -0.2 & 0.84 & -0.99 & 17.63 & 17.63 & 1.01 \\
\hline \multirow{4}{*}{ 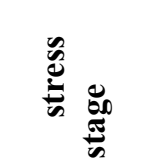 } & SAB-632 & 21.01 & 19.80 & 1.25 & 0.88 & 5.77 & 20.40 & 20.41 & 0.94 \\
\hline & SER-125 & 15.13 & 14.63 & 0.71 & 0.66 & 3.27 & 14.88 & 14.88 & 0.97 \\
\hline & Kat-B9 & 27.10 & 25.27 & 1.46 & 1.11 & 6.75 & 26.17 & 26.18 & 0.93 \\
\hline & $\mathrm{H} /$ dumme & 22.69 & 18.09 & 4.38 & 0.68 & 20.3 & 20.26 & 20.39 & 0.80 \\
\hline \multirow{5}{*}{ 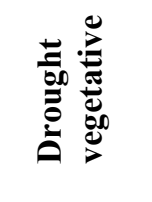 } & Ibbado & 30.45 & 30.37 & 0.06 & 1.42 & 0.27 & 30.41 & 30.41 & 1.00 \\
\hline & Wajo & 30.57 & 28.70 & 1.32 & 1.27 & 6.10 & 29.62 & 29.64 & 0.94 \\
\hline & Nasir & 21.37 & 20.51 & 0.87 & 0.92 & 4.05 & 20.94 & 20.94 & 0.96 \\
\hline & Red-Wolaita & 19.71 & 20.20 & -0.50 & 0.97 & -2.48 & 19.95 & 19.95 & 1.02 \\
\hline & Mean & 22.34 & 21.3 & 0.94 & 0.96 & 4.33 & 21.8 & 21.82 & 0.96 \\
\hline \multirow[t]{2}{*}{ ล } & SER-119 & 17.79 & 10.86 & 1.16 & 0.45 & 38.90 & 13.90 & 14.33 & 0.61 \\
\hline & Tatu & 17.55 & 13.92 & 0.62 & 0.74 & 20.70 & 15.63 & 15.73 & 0.79 \\
\hline \multirow{9}{*}{ 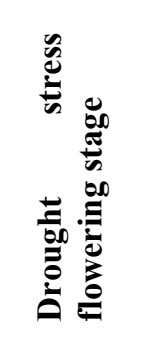 } & SAB-632 & 21.01 & 11.28 & 1.38 & 0.41 & 46.30 & 15.40 & 16.15 & 0.54 \\
\hline & SER-125 & 15.13 & 14.10 & 0.20 & 0.89 & 6.78 & 14.61 & 14.62 & 0.93 \\
\hline & Kat-B9 & 27.10 & 13.41 & 1.51 & 0.45 & 50.50 & 19.06 & 20.25 & 0.49 \\
\hline & $\mathrm{H} /$ dumme & 22.69 & 21.96 & 0.10 & 1.43 & 3.23 & 22.32 & 22.32 & 0.97 \\
\hline & Ibbado & 30.45 & 15.33 & 1.48 & 0.52 & 49.70 & 21.60 & 22.89 & 0.50 \\
\hline & Wajo & 30.57 & 21.38 & 0.90 & 1.01 & 30.10 & 25.56 & 25.97 & 0.70 \\
\hline & Nasir & 21.37 & 17.45 & 0.55 & 0.96 & 18.40 & 19.31 & 19.41 & 0.82 \\
\hline & Red-Wolaita & 19.71 & 8.82 & 1.65 & 0.27 & 55.30 & 13.18 & 14.26 & 0.45 \\
\hline & Mean & 22.34 & 14.85 & 0.95 & 0.71 & 32 & 18.06 & 18.59 & 0.68 \\
\hline \multirow{11}{*}{ 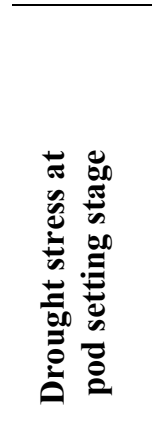 } & SER-119 & 17.79 & 12.02 & 1.29 & 0.49 & 32.40 & 14.62 & 14.91 & 0.68 \\
\hline & Tatu & 17.55 & 15.98 & 0.39 & 0.87 & 8.95 & 16.74 & 16.76 & 0.91 \\
\hline & SAB-632 & 21.01 & 13.63 & 1.53 & 0.53 & 35.10 & 16.92 & 17.32 & 0.65 \\
\hline & SER-125 & 15.13 & 15.02 & 0.03 & 0.89 & 0.69 & 15.08 & 15.08 & 0.99 \\
\hline & Kat-B9 & 27.10 & 15.02 & 1.94 & 0.50 & 44.60 & 20.18 & 21.06 & 0.55 \\
\hline & $\mathrm{H} /$ dumme & 22.69 & 20.43 & 0.43 & 1.10 & 9.96 & 21.53 & 21.56 & 0.90 \\
\hline & Ibbado & 30.45 & 18.06 & 1.77 & 0.64 & 40.70 & 23.45 & 24.25 & 0.59 \\
\hline & Wajo & 30.57 & 23.43 & 1.02 & 1.07 & 23.40 & 26.76 & 27.00 & 0.77 \\
\hline & Nasir & 21.37 & 19.10 & 0.46 & 1.02 & 10.60 & 20.20 & 20.24 & 0.89 \\
\hline & Red-Wolaita & 19.71 & 14.87 & 1.07 & 0.67 & 24.60 & 17.12 & 17.29 & 0.75 \\
\hline & Mean & 22.34 & 16.76 & 0.99 & 0.78 & 23.1 & 19.26 & 19.55 & 0.77 \\
\hline
\end{tabular}

Where Ypi $=$ yield under non-stressed condition, Ysi=yield under the stressed condition, DSI $=$ Drought susceptibility index, DTI= Drought tolerance index, PYR= Percentage of yield reduction due to drought, GM= Geometric mean, MP = Mean productivity, YSI =Yield stability index

\section{Correlations of seed yield with phenology, growth and yield components}

Seed yield was positively and significantly correlated with pod harvest index $(0.74 * * *)$, days to maturity $\left(\mathrm{r}=0.45^{* *}\right)$ and hundred seed weight $\left(\mathrm{r}=0.57^{* *}\right)$ under full irrigation. Pod harvest index $\left(0.72^{* * *}\right)$ days to emergence $\left(\mathrm{r}=0.36^{*}\right)$, days to maturity $\left(\mathrm{r}=0.5^{* *}\right)$ and hundred seed weight $\left(\mathrm{r}=0.52^{* *}\right)$ were positively and significantly correlated with seed yield under drought stress at vegetative stage. Under drought stress at flowering stage, seed yield had significant and positive correlation with days to flowering $\left(\mathrm{r}=0.46^{* *}\right)$, number of pods on main stem $\left(\mathrm{r}=0.36^{*}\right)$, number of seeds per plant $\left(0.76^{* * *}\right)$ and pod harvest index $\left(\mathrm{r}=0.86^{* * *}\right)$. Seed yield was significantly and positively correlated with days to maturity $\left(\mathrm{r}=0.44^{* *}\right)$, plant height $\left(\mathrm{r}=0.43^{*}\right)$, number of seeds per plant $\left(\mathrm{r}=0.63^{* *}\right)$, number of seeds per pod $\left(\mathrm{r}=0.47^{* *}\right)$ and pod harvest index $\left(0.73^{* * *}\right)$ during drought stress at pod setting stage. It was also reported that number of pods per plant and number of seeds 
per pod were highly correlated with grain yield under drought stress at different growth stages (Manjeru et al., 2005; Ambachew et al., 2015). Another study indicated that number of seeds per pod, number of pods per plant and seed weight also have strong correlation with yield under stress condition (Walelign and Skjelvag, 2006). Ambachew (2012) also reported that seed yield showed positive and significant correlation with pods per plant and seeds per pod at both phenotypic and genotypic levels, and under both moisture regimes. Therefore taller plant height, pods per plant, seeds per plant and pod harvest index can be used to develop drought tolerant haricot bean varieties.

\section{CONCLUSTION AND RECOMMENDATION}

Haricot bean growers could ensure that their crop must not suffer from drought stress during and after flowering stage. Farmers must adopt Response Farming or supplemental irrigation, but these require close contact between the farmers and meteorological stations. Under drought stress at vegetative growth stage varieties $\mathrm{H} /$ dumme, Wajo and Nasir are recommended, while under non-stress condition Wajo, H/dumme and Ibbado are high yielder. It is also confirmed that under moderate drought stress varieties with high yield potential are preferred. The response of varieties also varies depending on the stage of drought stress commencement. Plant breeders need to look for varieties like $\mathrm{H} /$ dumme in which most of the flowers found on the main stem, which are less susceptible for abortion as compared to flowers on branches. Traits like pod harvest index, days to maturity, number of pods on main stem, seed plant ${ }^{-1}, 100$ seed weight and plant height can be used by plant breeder as a morphological marker to screen drought tolerant varieties. The root systems of a crop grown in the field usually have access to much larger volumes of soil and water. Therefore, stresses would develop more slowly and take much longer to become severe than the short times that occurred in the pots suggesting the need for further supplementary field studies.

\section{REFERENCE}

AssefaTeshale, Beebe, S. E., Rao, I.M, Cuasquer, J. B., Duque, M. C., Riverab, M., Battisti, A. \& Lucchin, M. (2013). "Pod harvest index as a selection criterion to improve drought resistance in white pea bean". Field Crops Research, 148: 24-33.

Barrios, N.A., Hoogenboom, G. \& Nesmith, S.D. (2005). "Drought stress and the distribution of vegetative and reproductive traits of a bean cultivar". Sci. Agric., 62:18-22.

Beshir, H.M, Buckert, R. \&Taran, B. (2016). "Effect of temporary drought at different growth stages on snap bean pod quality and yield". African Crop Science Journal, 24:317-330.

Bolanos, J. \& Edmeas, G.O. (1993). "Eight cycle of selection for drought tolerance in low land tropical maize". In: CIMMYT, Response in grain yield, biomass and radiation utilization.

CIAT. (1986). "The cultivated species of Phaseolus: Study guide to be used as a supplement to the audio tutorial unit on the same topic”. In: R. Hidalgo, L. Song, P. Gepts (eds.) Colombia, California Pp. 52-58.

CSA (Central Statistical Authority). (2016). "Agricultural sample survey 2008/2009 E.C. Report on area and production for major crops". Statistical bullet in Addis Ababa, Ethiopia.

Daniel Ambachew, Firew Mekbib, Asfaw Asrat, Beebe, S.E., Matthew, W. \& Blair. (2015). "Trait associations in common bean genotypes grown under drought stress and field infestation by BSM bean fly". The crop journal, 3: 305 - 316.

Demirevska, K., Zasheva, D., Dimitrov, R., Simova-Stoilova, L., Stamenova, M. \& Feller, U. (2009). "Drought stress effects on Rubisco in wheat: changes in the Rubisco large subunit". Acta Physiol. Plant., 31: 11291138.

Emam, Y., Shekoofa, A., Salehi, F. \& Jalali, A.H. (2010). "Water stress effects on two common bean cultivars with contrasting growth habits". American-Eurasian J. Agric. \& Environ. Sci., 9: 495-499.

FAO (2012). "Crop-water productivity model to simulate yield response to water". FAO, Rome, Italy, Aqua Crop, version 4, Pp. 130. (https://wenku.baidu.).

Ferris, S. \& Kagnazi, E. (2008). "Evaluating marketing opportunities for haricot beans in Ethiopia, Improving Productivity and Market Success (IPMS) of Ethiopian Farmers Project”, International Livestock Research Institute (ILRI), Addis Ababa, Ethiopia.

Fikru Mekonnen. (2007). "Haricot ban (Phaseolus vulgaris L.) variety development in the lowland areas of Wollo". Proceedings of the $2^{\text {nd }}$ Annual Regional Conference on Completed Crops Research Activities 18 21 September 2007, Pp. 86-93, Bahir Dar, Ethiopia.

Gardner, F.P., Pearce, R.B. \& Mitchell, R.L. (1985). "Physiology of crop plants". Iowa State University Press, Ames, USA.

Jaleel, C.A., Gopi, R., Sankar, B., Gomathinayagam, M. \& Panneerselvam, R. (2008). "Differential responses in water use efficiency in two varieties of Catharanthusroseus under drought stress". Comp. Rend. Biol., 331: 42-47.

Javed, A., Ghulam, M.S., Makhdoom, H., Javed, A., Mujahid, H. \& Muhammad, M. (2011). "Drought tolerance 
indices and their correlation with yield in exotic wheat genotypes". Pak. J. Bot., 43: 1527-1530.

Kwabena Darkwa, Ambachew Daniel, Hussein Mohammed, Asfaw Asrat \& Matthew, W. Blair. (2016). "Evaluation of common bean ( Phaseolus vulgaris L.) genotypes for drought stress adaptation in Ethiopia". The crop journal, 4:367-376.

Manjeru, P., Madanzi, T., Makeredza, B., Nciizah, A. \& Sithole, M. (2005). "Effects of water stress at different growth stages on components and grain yield of common bean (Phaseolus vulgaris L.)". In ACSCP, pp. 299-303.

MoANR (Ministry of Agriculture and Natural Resource). (2003, 2008, 20012, 2013, 2014, 2016). Crop Variety Register. Animal and Plant Health Regulatory Directorate, Ethiopia.

Mustapha, Y., Biwe, ER. \& Salem, A. (2014). "Effects of moisture stress on the growth parameters of soybean genotypes”. Discourse Journal of Agriculture and Food Sciences. 2:142-8.

Nautiyal, P.C., Joshi, Y.C. \& Dayal, D. (2002). "Response of groundnut to deficit irrigation during vegetative growth". Food and Agricultural Organization of the United Nations (FAO) (ed.), Deficit Irrigation Practices. Rome, Italy, Pp. 39-46.

Panthuwan, G., Fukai, S., Cooper, M., Rajatasereekul, S. \& Toole, J.C. (2002).'Yield response of rice (Oryza sativa L.) genotypes to different types of drought under rain fed lowlands". Field Crop Res., 73:153-168.

Porch, T.G., Ramirez, V.H., Santana, D. \& Harmsen, E.W. (2009). "Evaluation of common bean for drought tolerance in Juana Diaz, Puerto Rico", J. Agron. Crop Sci., 195:328-334.

RezeneYayis, Gebeyehu Setegn \& Zelleke Habtamu. (2013). "Morpho-physiological response to post-flowering drought stress in small red seeded common bean (Phaseolus vulgaris L.) genotypes". Journal of Plant Studies, 2:1927-0461.

Schwartz, H.F., Brick, M.A., Nuland, D.S \& Franc, G.D. (1996). "Dry bean production and pest management.Regional bulletin”. Pp. 562.

Suzuki, K., Shono, M. \& Egawa, Y. (2003). "Occurrence of abnormal pods and abscission of flowers at high temperatures in snap bean". Research Highlights JIRCAS, Pp, 46-47.

Vijitha, R. \& Mahendran, S. (2010). "Effect of moisture stress at different growth stages of tomato plant on yield and quality of fruits". J. Sci. Univ. Kelaniya, 5: 1-11.

Walelign Worku \& Arne O.Skjelvag. (2006). "The effect of different moisture and light regime on productivity, light interception and use efficiency of common bean". SINET Ethiop.j.sci., 29:95-106.

Wortmann, C.S. \& Eledu, C.A. (1997). "Distribution of bean types in eastern Africa”. Ann. Report Bean Improv. Cooperative, 40: 30-31. 